\title{
RADIOCARBON DATES OF RIGA II
}

\author{
V S VEKSLER \\ All-Union Research Institute of Submarine Geology and Geophysics \\ Riga, USSR

\section{INTRODUCTION} \\ Our standard procedure of ${ }^{14} \mathrm{C}$ concentration measurements is \\ reported in Riga I. We report here data on samples from the Latvian SSR \\ and Eastern Siberia.
}

\section{GEOLOGIC SAMPLES \\ Latvia}

\section{Torfkaln Purvs Bog series}

Torfkaln Purvs Bog is SE of Riga, near Salaspils and contains highmoor type sediments. Its area is ca 160 ha. Average peat is $3.5 \mathrm{~m}$ thick, 4.8 max. The bog structure and characteristics were previously studied (Normals, 1943; Druvij \& Birkman, 1960).

The botanical composition of the peat indicates that all stages typical for this region of Latvia, from low-lying to highmoor peat bog, are present in the bog development. The absolute chronology of the bog has been described (Stelle, Savvaitov \& Veksler, 1974). Samples were subm by V Stelle.

Riga-21.

$2140 \pm 130$

Weakly decomposed sphagnum peat from 1.05 to $1.10 \mathrm{~m}$ depth.

Riga-18.

$2430 \pm 130$

Strongly decomposed sphagnum peat from 1.30 to $1.35 \mathrm{~m}$ depth.

Riga-18a.

$2410 \pm 80$

Humic acids of previous sample.

Riga-12.

$3880 \pm 140$

Weakly decomposed sphagnum peat, from 1.75 to $1.80 \mathrm{~m}$ depth.

\section{Riga-17.}

$\mathbf{5 2 9 0} \pm \mathbf{5 0}$

Strongly decomposed peat from 2.05 to $2.10 \mathrm{~m}$ depth.

Riga-17a.

$5360 \pm 60$

Humic acids of sample 17 .

Riga-13.

$5840 \pm 140$

Strongly decomposed peat, from 2.30 to $2.40 \mathrm{~m}$ depth. 
Riga-14.

$6430 \pm 130$

Moderately decomposed sphagnum peat, from 2.55 to $2.60 \mathrm{~m}$ depth.

Riga-20.

$7390 \pm 130$

Weakly decomposed sphagnum peat, from 2.75 to $2.80 \mathrm{~m}$ depth.

Riga-42.

$7450 \pm 130$

Strongly decomposed hypno-sedge peat, from 2.80 to $2.85 \mathrm{~m}$ depth.

Riga-10.

$7890 \pm 130$

Strongly decomposed hypno-sedge peat, from 2.85 to $2.90 \mathrm{~m}$ depth.

Riga-10a.

$7760 \pm 130$

Humic acids of sample 10.

Riga-15.

$8020 \pm 140$

Strongly decomposed hypno-sedge peat, from 2.90 to $2.95 \mathrm{~m}$ depth. Humid acid dating.

Riga-19.

$8890 \pm 140$

Strongly decomposed sedge peat, from 3.35 to $3.40 \mathrm{~m}$ depth.

Riga-16.

$9410 \pm 140$

Strongly decomposed sedge-equisetic peat, from 3.60 to $3.65 \mathrm{~m}$ depth. Humic acid dating.

\section{Sarnate Bog series}

Sarnate Bog is one of the reference chronological sequence sections of the Kurzeme coastline. It is $30 \mathrm{~km} \mathrm{~S}$ of the town of Ventspils. Its structure is characterized by a sequence of layers of bog and lake origin. The bog sediments are overlain by fine-grained sands and locally by grayish loamy clays.

Sporo-pollen analysis of the section and its radiocarbon dates (Table 1) were undertaken for the periphery, mainly low-lying peat, the sedimenta-

TABLE 1

Radiocarbon dates of Sarnate Bog

\begin{tabular}{|c|c|c|c|}
\hline Lab no. & $\begin{array}{l}{ }^{14} \mathrm{C} \text { date } \\
\text { (yr BP) }\end{array}$ & $\begin{array}{l}\text { Sporo-pollen } \\
\text { zone }\end{array}$ & Provenience \\
\hline Riga-38 & $7090 \pm 140$ & $\mathrm{BO} 2 / \mathrm{AT} 1$ & $\begin{array}{l}\text { Interface between Boreal and At- } \\
\text { lantic layers }\end{array}$ \\
\hline-29 & $7920 \pm 160$ & $\mathrm{BO} 2$ & Upper max of pine pollen \\
\hline-56 & $8150 \pm 130$ & $\mathrm{BO} 1$ & $\begin{array}{l}\text { Lower max of alder and hazel } \\
\text { pollen }\end{array}$ \\
\hline$-23 a$ & $8300 \pm 200$ & $\mathrm{BO} 1$ & $\begin{array}{l}\text { Offset of rational interface of alder } \\
\text { pollen }\end{array}$ \\
\hline-23 & $8520 \pm 200$ & $\mathrm{BO} 1$ & Lower Boreal max of pine pollen \\
\hline-25 & $8950 \pm 200$ & $\mathrm{BO} 1$ & \\
\hline-24 & $10,580 \pm 250$ & Dr3 & Hypnous peat horizon \\
\hline
\end{tabular}


tion of which occurred during the first half of the postglacial period (Stelle \& Veksler, 1975).

\section{Tirela Bog series}

Tirela Bog is in the thermokarst depression of the W Kurzeme upland, $10 \mathrm{~km} \mathrm{~S}$ of Edole. It is a highmoor-type peat reservoir, and measures $30 \mathrm{ha}$. Radiocarbon samples were coll in the central part of the bog and subm by $\mathrm{A}$ Lacis.

Riga-300.

Highmoor peat from 1.25 to $1.35 \mathrm{~m}$.

$4080 \pm 140$

Riga-301.

$4320 \pm 140$

Highmoor peat from 1.35 to $1.45 \mathrm{~m}$.

Riga-303.

$8400 \pm 150$

Magellanicum peat from 4.9 to $5.0 \mathrm{~m}$.

Riga-304.

$8520 \pm 140$

Magellanicum peat from 5.0 to $5.1 \mathrm{~m}$.

Riga-305.

$10,180 \pm 140$

Sapropel from clayey deposits; depth: 6.65 to $6.70 \mathrm{~m}$.

\section{Blidenes Bog series}

Blidenes Bog is in the limnoglacial plain of E Kurzeme upland near Blidenes and consists of two types of peat, highmoor and low-lying. Samples were coll in the NE part of the low-lying reservoir and subm by $\mathrm{A}$ Lacis.

Riga-308.

$5840 \pm 140$

Peat from 3.40 to $3.50 \mathrm{~m}$ depth.

Riga-307.

$7450 \pm 100$

Sapropel with peat laminae from 3.50 to $3.60 \mathrm{~m}$ depth.

Riga-306.

$9300 \pm 80$

Sapropel from 4.60 to $4.70 \mathrm{~m}$ depth.

\section{Lambartu Bog series}

Lambartu Bog is in the limnoglacial plain of Middle-Latvian lowland near Salenieki, Bauska region and measures 400ha. There are three types of peat-highmoor, mixed and low-lying. Samples were coll from the middle highmoor part of the reservoir, and subm by A Lacis.

Riga-317.

$2170 \pm 100$

Peat from 3.65 to $3.75 \mathrm{~m}$ depth. 
Riga-316.

Peat from 4.8 to $4.9 \mathrm{~m}$ depth.

Riga-315.

$4630 \pm 140$

Sapropel from 6.0 to $61 . \mathrm{m}$ depth.

Riga-314.

$6510 \pm 140$

Sapropel from 6.25 to $6.35 \mathrm{~m}$ depth.

\section{Gauya River series}

Samples Riga-74, -105, -75, -76, -77 were coll near Viesuleni from river bank. Samples subm by V Stelle.

Riga-74.

$11,110 \pm 350$

Hypnous peat from riverflat terrace alluvium III at 3.38 to $3.25 \mathrm{~m}$.

Riga-105.

$11,270 \pm 230$

Hypnous peat from same horizon.

\section{Riga-75.}

$8230 \pm 140$

Wood from dark-brown peat horizon at 2.35 to $2.25 \mathrm{~m}$.

Riga-76.

$1790 \pm 120$

Wood fragments from alluvial outcrop clearings in sands at 1.75 to $1.90 \mathrm{~m}$.

Riga-77.

$950 \pm 80$

Oak wood from alluvial flat in clayey sands at 0.95 to $1.60 \mathrm{~m}$.

\section{Riga-33.}

$10,530 \pm 250$

Small plant fragments from III river flat terrace, river bank $3 \mathrm{~km}$ from lower Valmiera. Subm by O Aboltinsš and V Stelle.

Riga-256.

$2770 \pm 300$

Wood from $4.5 \mathrm{~m}$ depth of river flat terrace of bank of lower Nurmižupite $\mathrm{R}$ delta.

Riga-319.

$3030 \pm 120$

Wood from 4.20 to $4.40 \mathrm{~m}$ depth of first terrace of bank of lower Nurmižupite $\mathrm{R}$.

Riga-318.

$1780 \pm 80$

Wood from 2.55 to $2.60 \mathrm{~m}$ depth from oxbow-lake sec of high river flat near Mucenieki near Nurmižupite R. Riga-256, -318, -319 subm by I Danilans.

Riga-72.

$21,420 \pm 440$

Buried peat from landslide near Adamovo on bank of Daugava $\mathrm{R} 3 \mathrm{~km}$ from lower Kraslava. 
Riga-263.

Wood peat with fragments of branches and yellow fine-grained sand laminae with transition to dark-gray rich in organic clay in lower part. Taken from 3.1 m depth from bank of Pededze R 250m from lower Sita R delta; subm by I Danilans.

Riga-320.

$3920 \pm 120$

Wood from $4.5 \mathrm{~m}$ depth in terrace I outcrop of bank of Daugava $R$ near Piedruya, subm by I Danilans.

Riga-323.

$7200 \pm 120$

Wood from same section at 5.8 to $6.0 \mathrm{~m}$ depth; subm by I Danilans.

Riga-257.

$3250 \pm 150$ lans.

Wood from layer $20 \mathrm{~m}$ above level of Maza Jugla R; subm by I Dani-

\section{Riga-37.}

$10,320 \pm 230$

Strongly decomposed peat under sands of local basin terrace, from $2.2 \mathrm{~m}$ depth on bank of Daugava $\mathrm{R}$ near Kaulezers Lake; subm by $\mathrm{O}$ Aboltinš, G Eberhard and V Stelle.

Riga-39.

$13,320 \pm 250$

Mossy peat with plant fragments from moraine of bank of Rauna R; subm by $\mathrm{O}$ Aboltinšs and V Stelle.

Riga-253.

$6560 \pm 250$ Danilans.

Wood from second river flat terrace of Ogra R near Sturiši; subm by I

Riga-258.

$\mathbf{3 7 5 0} \pm \mathbf{5 0}$ Danilans.

Wood from $5 \mathrm{~m}$ depth at bank of Bolshaya Jugla R near Zaki; subm by I

Riga-271.

$4950 \pm 60$

Peat from 3.6 to 3.2m depth near Kesterciems; subm by Z Meirons.

Riga-270.

$5300+240$

Humic acids of Riga-271.

Riga-140.

$10,650 \pm 190$

Sample of well-preserved pine wood from III river flat terrace of Memele R near Pinelupe; subm by I Straume.

Riga-69.

$9720 \pm 180$

Strongly decomposed peat with wood fragments from 2.90 to $3.05 \mathrm{~m}$ depth, under sediments of Runi $\mathrm{R}$ bank of oxbow lake, $12 \mathrm{~km}$ from Priekule. Subm by V Stelle. 
Riga-192.

$7750 \pm 180$

Wood from lower layer of gyttja of Ancylus lake regression at $3 \mathrm{~m}$ from surface on bank of Venta R near Varve. Assumed date: Holocene. Subm by I Veinberg.

Riga-189.

$9560 \pm 220$

Wood from contact of clays of Ancylus transgression and underlying sands from $2 \mathrm{~m}$ depth. Sample was taken from bank of Venta $\mathrm{R}$ opposite mouth of Packule R. Assumed date: Holocene. Subm by I Veinberg.

Riga-174.

$7640 \pm 150$

Sample from outcrop on bank of Irbe R from lowest part of gyttja overlain by littorina sands and silts, $6 \mathrm{~m}$ thick. Assumed date: Holocene. Subm by I Veinberg.

Riga-116.

$\mathbf{1 2 , 5 0 0} \pm \mathbf{5 0 0}$

Plant detritus from $2.5 \mathrm{~m}$ depth on bank of Iecava $\mathrm{R}$ near Ozolnieki. Subm by V Stelle.

\section{Eatern Siberia series}

Rig a-207.

$2070 \pm 120$

You ag tree branch $5 \mathrm{~cm}$ in diam, with 5- to 6-yr rings. Sample taken from scarp of Konda $\mathrm{R}$ in layer of frozen peat.

Riga-203.

$3630 \pm 110$ depth.

Wood from scarp on bank of Konda R $10 \mathrm{~km}$ from its delta, 2.0 to $2.1 \mathrm{~m}$

Riga-204.

$5370 \pm 160$

Same as Riga-203, 5.2 to $5.5 \mathrm{~m}$ depth.

Riga-205.

$3660 \pm 120$

Same as Riga-203, 6.85 to $7.1 \mathrm{~m}$ depth.

Riga-199.

$3720 \pm 150$

Same as Riga-203, 10.1 to $10.25 \mathrm{~m}$ depth.

Riga-206.

$3520 \pm 160$

Same as Riga-203, 11.15 to $11.25 \mathrm{~m}$ depth.

Riga-208.

$3500 \pm 170$

Well-preserved brown wood from outcrop of $4 \mathrm{~m}$ terrace from bank of Chara $\mathrm{R}$ in town of Chara, Kalarski region, Chita. Sediments are of channel-alluvial type.

Riga-202.

$10,620 \pm 220$

Wood taken from bank of Mui R. Assumed date: upper PleistoceneHolocene. 
Riga-298.

$11,840 \pm 250$

Well-preserved wood from spruce root on terrace-like surface of bank of Mui R near Ust-Muya, Buryat ASSR. Assumed date: Holocene-upper
Pleistocene.

\section{Riga-198.}

$12,920 \pm 210$

Wood branch $20 \mathrm{~cm}$ in diam; last 30 rings in sample. Coll from same point as Riga-202, above.

\section{Riga-322.}

Slightly carbonized wood, buried in sediments of Late Neogene, from boring at 200m depth near Ust-Muya, Buryat ASSR. Riga-201, -205, -208, $-198,-199,-298,-322$ subm by A Kulchitski.

\section{Riga-126.}

$$
\mathbf{3 9 , 0 0 0} \pm 680
$$

Very earthy peat from lower part of humus horizon on surface of III Baikal terrace, W Sv Nos peninsula, Buryat ASSR.

\section{Riga-127.}

$$
37,000 \pm 520
$$
Riga-126.

Earthy peat from buried soil on surface of III Baikal terrace; same as

\section{Riga-128.}

$35,200 \pm 510$ 126.

Upper part of buried soil of III Baikal terrace surface; same as Riga-

\section{Riga-62.}

$\geqslant 39,200$

Humic acids from soil-peat humus layer of moraine, Cape Omagachan, Buryat ASSR.

\section{Riga-58.}

$1840 \pm 30$

Peat from bog with fire horizons at $0.5 \mathrm{~m}$ depth, on surface of $8 \mathrm{~m}$ Baikal terrace, Cape Bireya, Buryat ASSR.

\section{Riga-68.}

$22,280 \pm 450$

Well-decomposed peat from humus horizon, under deluvial-proluvial sediments at $6.3 \mathrm{~m}$ depth on surface of $12 \mathrm{~m}$ Baikal terrace, $\mathrm{W}$ bank of $\mathrm{Sv}$ Nos peninsula, Buryat ASSR.

\section{Riga-52.}

Coal forest fire from coal buried under aeolian sands on surface of 7.5m Baikal terrace, Cape Peschaniye Bugri, Buryat ASSR.

\section{Riga-53.}

Coal from forest fire from same section as Riga-52. Comment: all samples except Riga-127 subm by V Mats. 
Riga-139.

$6750 \pm 100$

Peat with plant fragments, from $\mathrm{W}$ bank of Tiya $\mathrm{R}$ delta at $\mathrm{N}$ part of Lake Baikal. Subm by E Karabanov.

\section{ARCHAEOLOGIC SAMPLES}

\section{Irkutsk series}

Riga-50.

$7000 \pm 150$

Coal from cultural horizon VI from Goreliy Les site, Irkutsk region.

Riga-51.

$8440 \pm 120$

Coal from cultural horizon VII; from Goreliy Les site, Irkutsk region.

Riga-71.

$770 \pm 100$

Coal from surface of tomb at depth $0.85 \mathrm{~m}$ at Ust-Belaya site, Irkutsk region. Samples subm by N Savelyev.

\section{REFERENCES}

Druviet, R Ya and Birkman, Zh M, 1960, Peat deposits of the Latvian SSR and their utilization: Riga (in Russian).

Normals, P A, 1943, A survey of bogs in Vidzeme and Latgale: Riga (in Latvian).

Stelle, V Ya, Savvaitov, A S and Veksler, V S, 1974, Stratigraphy and absolute chronology of the Salaspils section, in All-Union seminar astrophysical phenomena and radiocarbon, Proc: Tbilisi, p 352-358 (in Russian).

Stelle, V Ya and Veksler, V S, 1975, Radiocarbon dating of Sarnate bog deposits, in Seminar, experience and methods of isotope-geochemical studies in the Baltic Republics of the USSR and Byelorussia, Proc: Riga, p 82-84 (in Russian). 